\title{
Ethnobotanical study and phytochemical profiling of Heptapleurum hypoleucum leaf extract and evaluation of its antimicrobial activities against diarrhea-causing bacteria
}

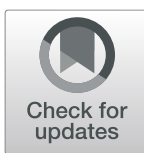

S. M. Rakib-Uz-Zaman ${ }^{1 * \dagger}$, Asif Iqbal ${ }^{1+}$, Sadrina Afrin Mowna', Mst Gitika Khanom², Mohammad Mastak Al Amin ${ }^{1}$ and Kashmery Khan ${ }^{1}$

\begin{abstract}
Background: Due to the development of superbugs as a result of unprescribed and frequent use of antibiotics in recent years, an alternate form of medicine had to be introduced. In light of this global threat, researchers all over the world have been gravitating towards herbal medicines. In order to find out new ways of saving the planet using medicinal plants, ethnobotanical studies must be carried out. Concerning this, an ethnobotanical study has been done in this paper to identify potential medicinal plants in Rangamati, Bangladesh.

Results: For the ethnobotanical survey, randomized 104 people were interviewed and 62 different plant species were found to treat 19 different kinds of diseases and $84 \%$ of people reported to be completely recovered. Furthermore, among the 19 diseases found, the majority of them were common cold, abdominal pain or gastric, diarrhea, and dysentery. From the 62 different plant species, Heptapleurum hypoleucum, used for the treatment of diarrhea, was selected for conducting further studies due to its heavy use as reported by the tribal people. In this study, the aqueous, ethanol, and methanol extracts of Heptapleurum hypoleucum were subjected to microbial susceptibility assays using the agar well diffusion method. The test microorganisms were Salmonella typhi, Streptococcus pneumoniae, Staphylococcus aureus, Shigella flexneri, and Escherichia coli. Among these, the most susceptible organisms were Staphylococcus aureus $(21 \mathrm{~mm})$ and Salmonella typhi $(19 \mathrm{~mm})$ in the ethanolic extract. Also, the methanolic extract showed an inhibition zone of $13 \mathrm{~mm}$ against $E$. coli, which was more than that of the antibiotic's $(11 \mathrm{~mm})$. Phytochemical screening of the plant revealed that it contains alkaloids, phenols, steroids, and flavonoids, but lacks saponins and tannins.

Conclusion: To combat the rising threat of antibiotic resistance, ethnoscience needs to be consolidated with modern biotechnological techniques to make the most use of the vast amount of natural resources. The findings of this study indicate that Heptapleurum hypoleucum, an ethnobotanical medicinal plant, has shown comparable antimicrobial activity with commercial antibiotics against several diarrhea-causing pathogens and also contains several medically important phytochemicals.
\end{abstract}

Keywords: Ethnobotanical study, Phytochemical screening, Medicinal plants, Diarrhea, Herbal medicines, Heptapleurum hypoleucum, Antimicrobial activity, Antibiotic resistance

\footnotetext{
* Correspondence: rakib.zaman@bracu.ac.bd

${ }^{\dagger}$ S. M. Rakib-Uz-Zaman and Asif lqbal contributed equally to this work. 'Biotechnology Program, Department of Mathematics and Natural Sciences, School of Sciences, BRAC University, Dhaka, Bangladesh

Full list of author information is available at the end of the article
}

\section{Springer Open}

(- The Author(s). 2020 Open Access This article is licensed under a Creative Commons Attribution 4.0 International License, which permits use, sharing, adaptation, distribution and reproduction in any medium or format, as long as you give appropriate credit to the original author(s) and the source, provide a link to the Creative Commons licence, and indicate if changes were made. The images or other third party material in this article are included in the article's Creative Commons licence, unless indicated otherwise in a credit line to the material. If material is not included in the article's Creative Commons licence and your intended use is not permitted by statutory regulation or exceeds the permitted use, you will need to obtain permission directly from the copyright holder. To view a copy of this licence, visit http://creativecommons.org/licenses/by/4.0/. 


\section{Background}

The discovery of antibiotics has been a blessing to the modern world. Sadly, the uncontrolled and unprescribed use of antibiotics has turned them into the enemy of human existence as microorganisms are becoming multidrug resistant. Given this, researchers and scientists agree that medicinal plants are a substantial alternative to this global crisis [1]. However, to discover new species of medicinally important plants, ethnobotanical surveys are needed to be conducted. In respect to that, an ethnobotanical study has been done as a part of this research paper to identify some of the plants used by tribal people in Rangamati, Bangladesh.

Medicinal plants are a common phenomenon in various continents and are also an essential source of different medicines [2]. Being a developing country, the use of medicinal plants in Bangladesh is notable in many regions. Therefore, medicinal plants have become one of the leading choices for treating different injuries and diseases. A significant portion of the plant species has been recognized as valuable resources of natural antimicrobial compounds which can be used as an alternative for the treatment of antibiotic-resistant bacterial infections [3]. They are the most suitable solution to the problems regarding antibiotic resistance, as they are cost-effective and have the least amount of side effects [4]. Medicinal plants exhibit antibacterial activities because of the phytochemicals produced during the secondary metabolism of the plants [5-7]. Plants are rich in a wide variety of secondary metabolites, including tannins, alkaloids, phenolic compounds, and flavonoids $[8,9]$. These phytochemicals are known to exhibit anti-inflammation, antimicrobial, and antifungal activities [5]. Reports suggest that phenolic and flavonoid compounds prevent diseases such as cancer, heart problems, cataracts, eye disorders, and Alzheimers [6]. The most vital properties of flavonoids include their ability to protect against oxidative diseases, reduce the oxidation of low-density lipoproteins to provide protection against cardiovascular diseases, and activate or inhibit various enzymes bind specific receptors [10].

Moreover, it is suggested that herbal extracts may be an effective alternative to antibiotics in order to cure common recurrent diseases like diarrhea, skin disease, throat, or ear infection [11]. Surprisingly, medicinal plants have also shown their efficiency in treating diabetes due to the presence of carotenoids, flavonoids, terpenoids, alkaloids, and glycosides [12]. The anti-hyperglycemic effects that result from treatment with plants are often due to their ability to improve the performance of pancreatic tissue, which is done by increasing insulin secretions or reducing the intestinal absorption of glucose [13].

A survey conducted among the Santal tribe of Joypurhat District, Bangladesh, found 33 plant species that were used by the tribal people for treating diabetes (A.H.M [14]).

Ethnobotanical surveys in our country $[15,16]$ have brought plants having effective medicinal characteristics into attention. Some studies have been done specifically to search for different medicinal plants, which are being used for the treatment of diarrhea and dysentery [17, 18]. After conducting the survey, a medicinal plant-Heptapleurum hypoleucum, locally known as Jharobbo hogoeya (Bangladesh Ethnobotany Online Database), was collected to evaluate its antibacterial activity against some pathogenic microorganisms responsible for causing diarrhea. This plant grows in the forest regions of the Rangamati, and people from the survey have claimed to use this plant for the treatment of diarrhea and dysentery. Tribal people are extremely experienced as they have been treating diseases using medicinal plants since prehistoric times and thus are knowledgeable about herbal medicine including those used for the treatment of diarrhea (M.S. [16]).

In this study, the test microorganisms were Salmonella typhi, Streptococcus pneumoniae, Staphylococcus aureus, Shigella flexneri, and Escherichia coli. The aqueous, ethanol, and methanol extracts of Heptapleurum hypoleucum were subjected to microbial susceptibility assays using the agar well diffusion method. After the phytochemical screening of plant extract, we have successfully detected alkaloids, phenolics, steroids, and flavonoids in different solvents. However, no saponins and tannins were identified in our extract. This study reveals the antibacterial effects of ethnobotanical medicinal plants as well as the presence of phytochemicals that may have antimicrobial activity against diarrhea-causing pathogenic microorganisms.

\section{Methods}

\section{Survey site selection}

The region selected for this research purpose has an area of $6116.13 \mathrm{~km}^{2}$ and is located in between $22^{\circ} 27^{\prime}$ and $23^{\circ} 44^{\prime}$ north latitudes and in between $91^{\circ} 56^{\prime}$ and $92^{\circ} 33^{\prime}$ east longitudes. Approximately 5,08,182 people live here and the main indigenous communities that live here are Chakma, Monipuri, Tripura, Khumi, Marma, Tanchangya, Santal, Mro, and many more.

\section{Ethics and consent to participate}

The purpose of our study was elaborately explained to each informant and verbal consent was taken to avoid any misunderstanding. We have also taken permission from the local authority to conduct the survey. As our study only dealt with the medicinal plants with no intention to conduct any trials on human, formal institutional consent for this study is not required. In addition, Bangladesh Medical Research Council Ethical Guidelines for Conducting Research Studies Involving Human 
Subjects deemed ethics approval unnecessary for this kind of study on page 39 , section 10.5.2.

\section{Data analysis}

All the data were listed alphabetically and ordered by the plant's scientific name, local name, plant part used, name of the disease, and mode of preparation of the plant. Also, the data were analyzed in the "IBM SPSS Statistics 25" software and graphical presentations were made.

\section{Antibacterial activity test Test organisms}

The pathogenic test organisms used in this assay are as follows: Salmonella typhi, Streptococcus pneumoniae, Staphylococcus aureus, Shigella flexneri, and Escherichia coli, all are known diarrhea-causing bacteria. The bacterial cultures were obtained from the Biotechnology and Molecular Biology Laboratory of the Department of Mathematics and Natural Sciences at BRAC University and the International Centre for Diarrheal Disease Research, Bangladesh (ICDDR, B).

\section{Sample collection and processing}

With the help of some local practitioners, parts of the Heptapleurum hypoleucum plant were taken and identified. The stem of the plant was used as the sample for this research work, obtained from the rural areas of Rangamati district. The stem was washed, cleaned, and air dried under open light for several days. As soon as it dried, it was mashed into powder.

\section{Preparation of extracts using different solvents Ethanolic extraction}

Ten grams of powdered sample was dissolved in $100 \mathrm{ml}$ of absolute ethanol in a conical flask, covered with aluminum foil and then kept at $37^{\circ} \mathrm{C}$ in a shaker incubator at $120 \mathrm{rpm}$ for $24 \mathrm{~h}$. Using an autoclaved filter paper, the filtrate was collected slowly in a conical flask and then evaporated using a rotary evaporator till the final volume was reduced to one-fourth of the original volume of the solvent used. This concentrated extract solution was poured on a sterile petri dish lid and kept in the incubator at $55^{\circ} \mathrm{C}$ for $20 \mathrm{~min}$. Finally, a sticky semisolid extract appeared on the surface of the plate when all the solvent was evaporated. The extract was collected and stored in a McCartney bottle that was autoclaved and weighed. The extract inside the bottle was weighed, recorded, and the exact amount of the extract was calculated by subtracting the mass of the empty bottle. Then the bottle was labeled and stored at $4{ }^{\circ} \mathrm{C}$ in the refrigerator.

\section{Methanolic extraction}

Ten grams of powdered sample was dissolved in $100 \mathrm{ml}$ of absolute methanol in a conical flask, covered with aluminum foil and then kept at $37^{\circ} \mathrm{C}$ in a shaker incubator at $120 \mathrm{rpm}$ for $24 \mathrm{~h}$. The filtrate was collected slowly in a conical flask using an autoclaved filter paper. It was then evaporated using a rotary evaporator till the final volume was reduced to one-fourth of the original volume of the solvent used. Then the concentrated extract solution was poured on a sterile petri dish lid and kept in the incubator at $55^{\circ} \mathrm{C}$ for $20 \mathrm{~min}$. Finally, a sticky semi-solid extract appeared on the surface of the plate when all the solvent was evaporated. The extract was collected and stored in a McCartney bottle that was autoclaved and weighed. The extract inside the container was weighed, recorded, and the exact amount of the extract was calculated by subtracting the mass of the empty bottle. Then the bottle was labeled and stored at $4{ }^{\circ} \mathrm{C}$ in the refrigerator.

\section{Aqueous extraction}

Ten grams of powdered sample was weighed and mixed with $100 \mathrm{ml}$ of distilled water in a conical flask, covered with aluminum foil. Then kept at $37^{\circ} \mathrm{C}$ in a shaker incubator at $120 \mathrm{rpm}$ for $24 \mathrm{~h}$. Using an autoclaved Whatman No.1 filter paper, the filtrate was collected slowly in a conical flask and then stored inside autoclaved falcon tubes at $4{ }^{\circ} \mathrm{C}$ in the refrigerator.

\section{Preparation of extract solution for antibacterial activity test}

The following formula was used to determine the amount of solvent to be added for making the extract solution for antibacterial activity test.

$$
\text { Amount of solvent to be added }=\frac{100 \times \text { amount of extract obtained }}{\text { amount of plant powder used }}
$$

\section{Agar well diffusion}

Antibacterial activity of aqueous and solvent extracts was determined based on agar well diffusion method developed by Clinical and Laboratory Standards Institute, USA with some modifications depending on our laboratory conditions [19].

Plates of bacterial strains were taken in the laminar hood. A loop was sterilized in the Bunsen flame and was used to scrape off the bacteria and dipped into the test tubes containing saline solution (each containing $9 \mathrm{ml}$ of $\mathrm{NaCl}$ ) to make a suspension. The test tubes were vortexed and the turbidity of the suspension was visually compared with the $0.5 \%$ MacFarland standard solution in order to keep the number of bacteria in the saline suspension within a given range for standardizing the lawn culture of antimicrobial tests. Then, an autoclaved 
cotton swab was dipped into the suspension and pressed against the inner walls of test tubes to remove excess liquid before taking them out. The cotton swab was rubbed horizontally across the surface of the labeled Mueller Hinton Agar (MHA) plates to conduct the lawn culture of the bacterial strains. A cork borer was heated to sterilize, cooled, and then pressed onto the MHA plates to create the required number of wells on the quadrants of the agar. After that, each well was labeled and filled with $60 \mu \mathrm{L}$ of diluted methanolic, ethanolic, and aqueous extracts, respectively. Different antibiotic disks were used as a positive control and placed onto one quadrant. Then the MHA plates were kept in the incubator for $24 \mathrm{~h}$ at $37^{\circ} \mathrm{C}$ and the results were observed and recorded the next day.

All the tests were conducted 3 times to obtain the average value of zones of inhibition. The zones were measured using a millimeter scale and then the activity index for each extract was calculated.

The following formula was used for calculating the activity index:

Activity index $=\frac{\text { zone of inhibition of plant extract }}{\text { zone of inhibition of antibiotic disc }}$

\section{Biochemical assays and phytochemical analysis}

The plant extracts in methanolic, ethanolic, and aqueous solutions were assessed for the existence of the phytochemical compounds based on the following standard methods [20-23].

\section{Tests for alkaloids}

The methanolic extract was diluted in an acidic solution of $\mathrm{HCl}$. This test solution was used for the detection of alkaloids using various reagents.

Hager's test: $1 \mathrm{ml}$ of extract was carefully mixed with 3 drops of freshly prepared Hager's reagent in a test tube. The formation of yellow precipitates represents a positive result and the presence of alkaloids in the extract.

Wagner's test: $1 \mathrm{ml}$ of extract was mixed in a test tube with 3 drops of Wagner's reagent prepared beforehand. The formation of brown precipitate will indicate the presence of alkaloids.

Dragendraff's test: $2 \mathrm{ml}$ of extract was taken in a test tube with $0.2 \mathrm{ml}$ diluted $\mathrm{HCl}$ and $1 \mathrm{ml}$ of Dragendraff's reagent and left for a few minutes. A positive result is indicated by the presence of an orange-brown precipitate.

\section{Test for steroidal compounds}

Salkowaski's test: $0.5 \mathrm{~g}$ of the extract was dissolved in 2 $\mathrm{ml}$ chloroform in a test tube. Concentrated sulfuric acid was carefully added on the wall of the test tube to form a lower layer. A reddish-brown color at the interface will indicate the presence of a steroid ring.

\section{Test for phenolic compounds}

Equal amounts of $1 \%$ ferric chloride solution and $1 \%$ potassium ferrocyanide were mixed. Then, 3 drops of this freshly prepared mixture were added to $2 \mathrm{ml}$ extract. The formation of a bluish-green color will represent a positive result.

\section{Test for flavonoids}

Reaction with sodium hydroxide: $2 \mathrm{ml}$ diluted $\mathrm{NaOH}$ solution was added to $3 \mathrm{ml}$ of extract. The mixture was inspected for the production of yellow color, which is considered positive.

\section{Tests for saponins}

Froth test: $0.5 \mathrm{~g}$ of the extract was dissolved in $10 \mathrm{ml}$ distilled water. The test tube was stoppered and then shaken vigorously for $30 \mathrm{~s}$. It was then allowed to stand for $30 \mathrm{~min}$. Formation and retention of honey-comb froth on the surface for $30 \mathrm{~min}$ is considered positive for saponins.

\section{Tests for tannins}

Lead acetate test: $5 \mathrm{ml}$ of extract and a few drops of freshly prepared $1 \%$ lead acetate were dissolved together. The formation of a yellow precipitate is considered a positive result.

\section{Results}

\section{Ethnobotanical survey}

In this survey, it was found that 101 people out of 104 have used or been using medicinal plants. Eighty-five people reported to be fully recovered using the respective medicinal plants, 15 people recovered partially, and 7 people faced some side effects during their treatment. From Table 1, we can see that the percentage of people using medicinal plants was the highest (30.77\%) for the age group 30-40 and the percentage of people aged above 60 was the least (6.73\%). The second-highest percentage $(26.92 \%)$ of people using plants as medicine was for the age group 51-60, while the second least percentage $(11.54 \%)$ of people using herbs was aged less than 30. Medicinal plants were used more by men $(74.04 \%)$ than women $(25.96 \%)$. Most people using herbal medicines had a job or a business $(20.19 \%$ both) and the second-highest percentage of people using medicinal plants were housewives (17.31\%). Farmers (14.42\%) and workers $(11.54 \%)$ seemed to use herbal medicines more than unemployed people (8.65\%), although, still less than housewives. Lastly, the lowest number of people (1.92\%) utilizing herbs were guide by profession (Table 1 ). 
Table 1 Demographic data of the informants. The percentage of people using medicinal plants was highest (30.77\%) for the age group 30-40 and the percentage of people aged above 60 was the least (6.73\%). In addition, considering the profession, students (5.77\%) and guides (1.92\%) used the least amount of herbal medicine, while local businessmen and job holders used the highest amount (both 20.19\%) of medicinal plants to treat different diseases and illness

\begin{tabular}{llll}
\hline Variable & Categories & Frequency $(n=104)$ & Percentage $(\%)$ \\
\hline Age & $<30$ & 12 & 11.54 \\
& $30-40$ & 32 & 30.77 \\
& $41-50$ & 25 & 24.04 \\
\multirow{6}{*}{ Gender } & $51-60$ & 28 & 26.92 \\
& Above 60 & 7 & 6.73 \\
& Male & 77 & 74.04 \\
& Female & 27 & 25.96 \\
& Worker & 12 & 11.54 \\
& Job & 21 & 20.19 \\
& Housewife & 18 & 17.31 \\
& Guide & 2 & 1.92 \\
& Business & 21 & 20.19 \\
& Farmer & 15 & 14.42 \\
& Unemployed & 9 & 8.65 \\
& Student & 6 & 5.77
\end{tabular}

In this survey, $42.86 \%$ of the plant part used were the leaves, confirming the fact that leaves are the most used part of a plant (Fig. 1). The second most used parts were fruits and whole plants, each having $15.65 \%$ of the total count. The least used parts were the seed and bulb, having just $1.36 \%$ each. The second least used parts were the rhizome and stem, being only $2.04 \%$ each. The percentage of bark used $(8.84 \%)$ can be termed as the third least part used as it has a higher percentage of use than the seed, rhizome, bulb, and stem. The root $(10.20 \%)$ is utilized more than the bark but still less than the fruit, whole plant, and leaves (Fig. 1).

In this survey, 33 people preferred to make "paste" from the plant parts (Fig. 2), which is also the highest count and shows the highest percentage (23.91\%). From Fig. 2, we can see that plant parts were also taken in the form of "juice" by 31 people, which is the second-highest form $(22.46 \%)$. In addition, 23 and 20 people used the "decoction" (16.67\%) and "extraction" (14.49\%) method respectively. Twenty-one people took the whole plant as medicine or processed in some way like cooking (15.22\%), which is lower than for the decoction method and higher than for the extraction method. The lowest number of people, 3 , took the plant in a powdered form $(2.17 \%)$ and the second-lowest number of people, 7 , used the plant as an infusion (5.07\%). In summary, the highest percentage of people used medicinal plants in the form of "paste," while the least number of people used the plant in the "powdered" form.

A wide range of diseases was cured using different kinds of plants. The diseases include minor injuries, common viral infections, and also bacterial diseases, all common throughout our country, Bangladesh. In this survey, common cold, abdominal pain, diarrhea, dysentery, and allergy or rashes are the most common ones, including 19 types of different diseases in total. From Fig. 3, we can conclude that anemia, piles, and measles were the least common. The highest count of

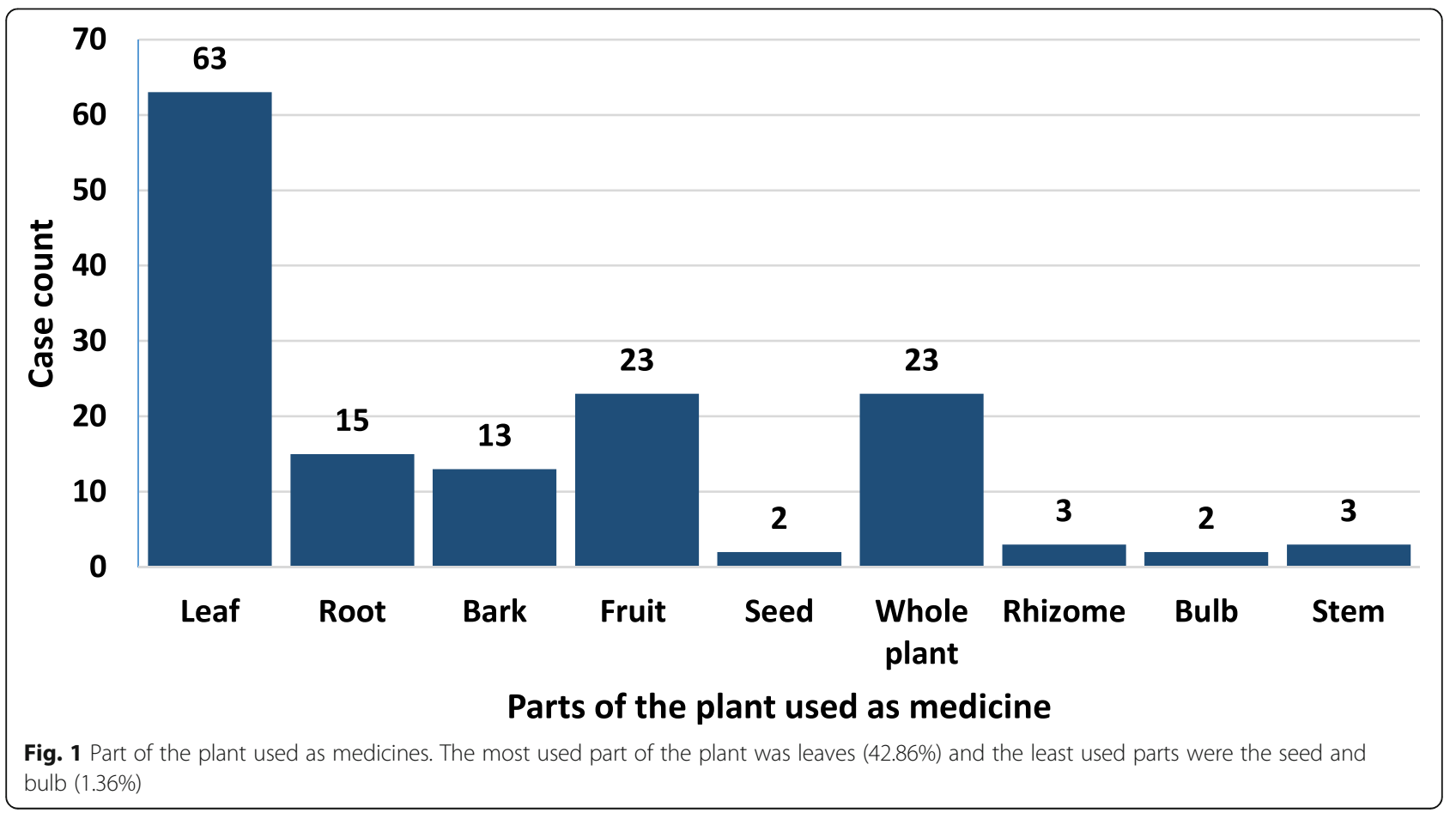




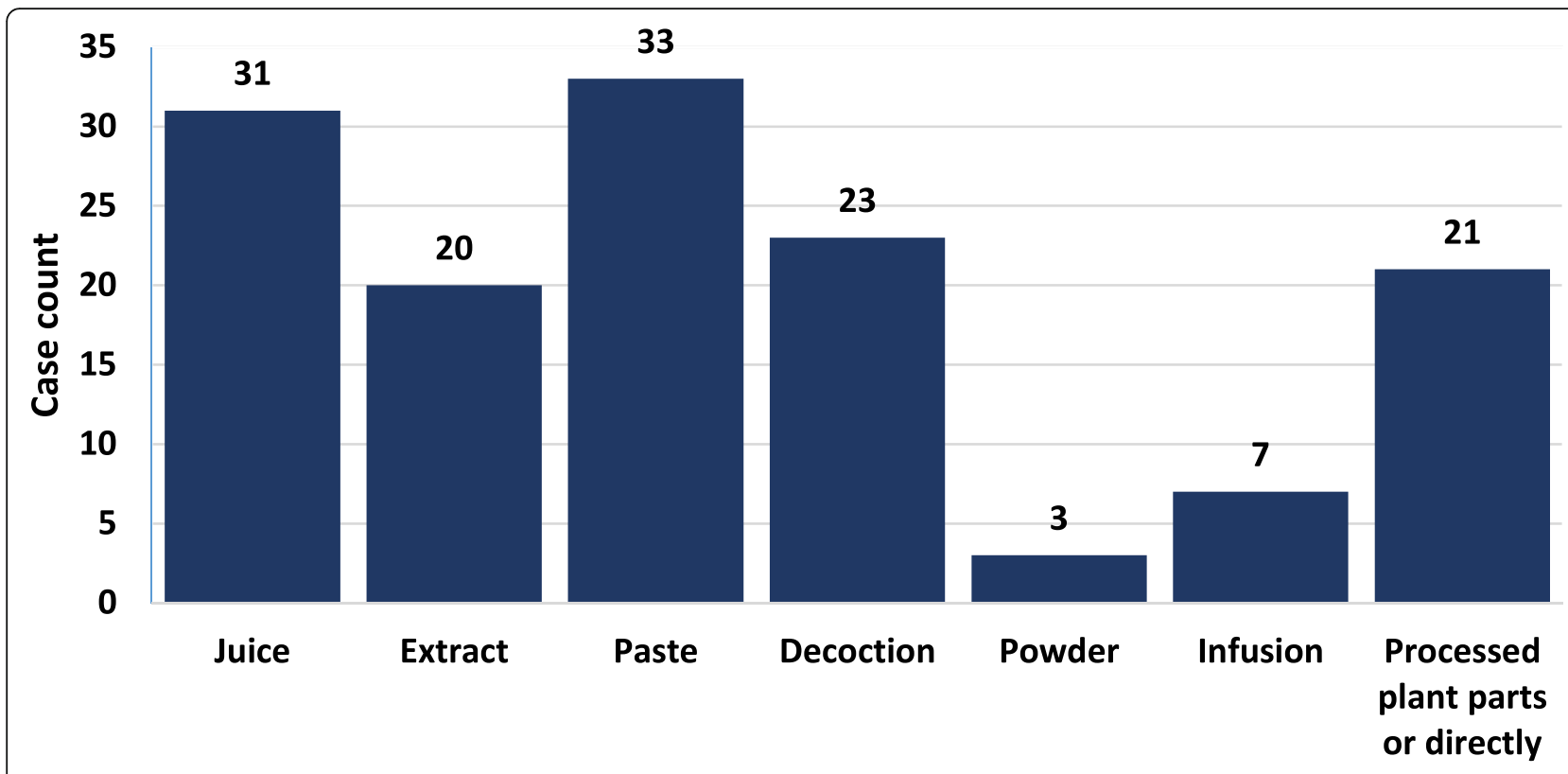

\section{Mode of preperation}

Fig. 2 Mode of preparation of plant parts. The most used form of preparation was "paste" (23.91\%) and the least used was "powder" (2.17\%)

occurrence was for common cold, while the secondhighest count was for diarrhea among the participants of this study. The least count of occurrence was for piles and the second least count was for both anemia and measles. Although the count of occurrence was quite high for dysentery and abdominal pain and gastric, it was still lower than for common cold, throat pain, and diarrhea. The cases of arthritis, diabetes, worms, hypertension, fever/dengue, constipation, snake-bite, and asthma were very low, but they were still higher than the occurrence of piles, allergy, jaundice, eczema/skin disease, and bleeding from wounds (Fig. 3).

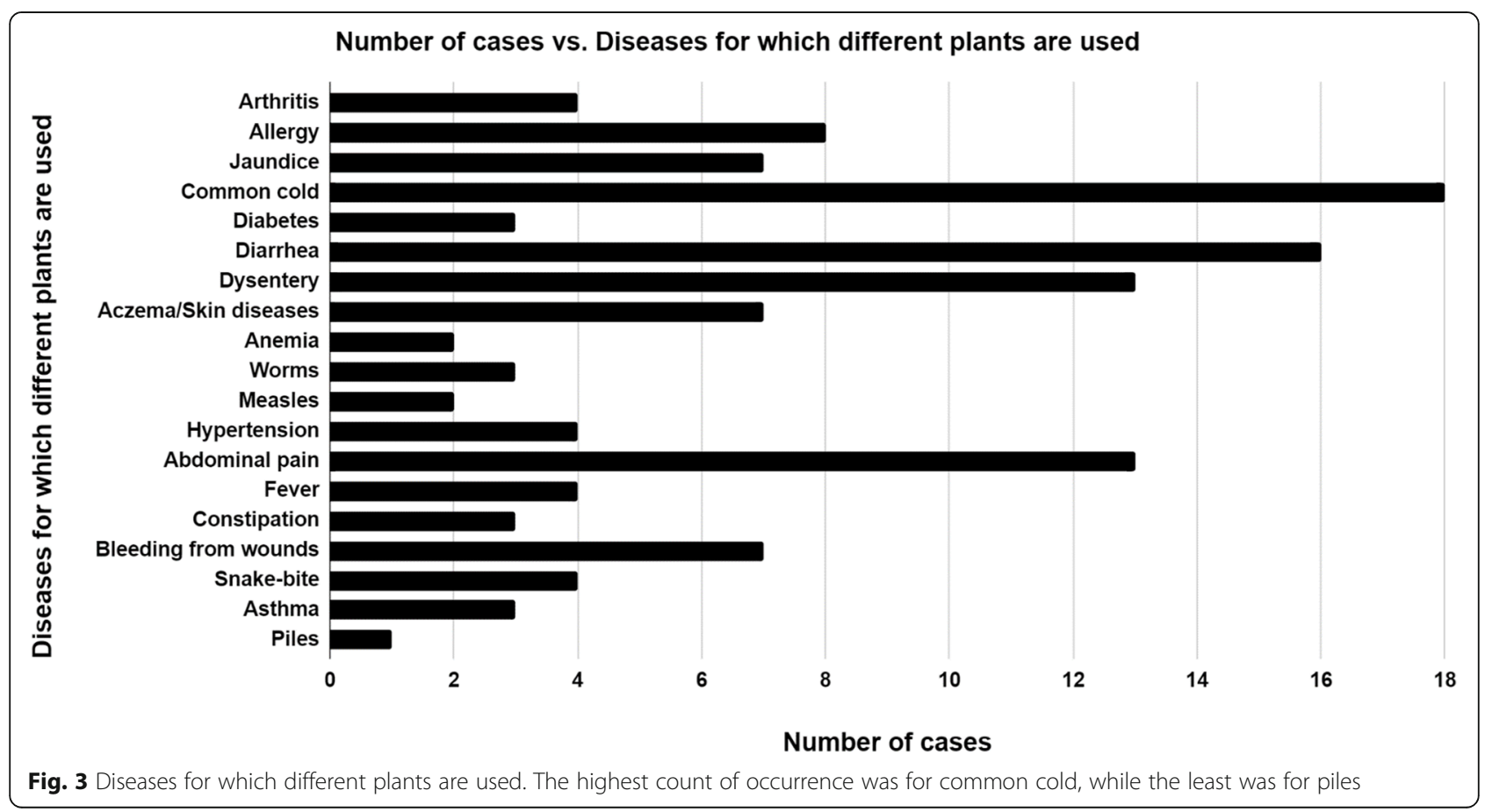


Table 2 Ethnomedicinal plants used by the tribal people of Rangamati for treating different diseases (source: Medicinal Plants Database of Bangladesh [24-26]). A total of 62 medicinal plant species were found out of which 26 plants treat gastrointestinal ailments (GIA), 12 plants treat respiratory system disorders (RSD). Poisonous bites (PB) and skeleton muscular system disorders (SMSD) were treated by 2 plants. Endocrinal disorders (ED), throat pain, and hemorrhoids (HEM) were healed by 3 plants. Four plants were used to cure different types of fever (Fvr). For liver problems (LP), 5 plants were used. Dermatological infections/diseases (DID) were treated using 9 different plants. Three plants were used to treat hypertension (HTN) and 2 were used to treat anemia

\begin{tabular}{|c|c|c|c|c|}
\hline Botanical/scientific name of the plant & Local name & Illness/disease treated & Part of the plant used & Mode of preparation \\
\hline Aegle marmelos & Bel & Abdominal pain, diarrhea & Fruit & Juice \\
\hline Allium sativum & Roshun & Common cold & Bulb & Juice \\
\hline Alocasia cucullate & Bilai kochu & Snake bite & Leaves & Paste \\
\hline Aloe Barbadensis & Ghritokumari & Constipation & Whole plant & Juice \\
\hline Andrographis paniculate & Kalomegh & Diabetes & Whole plant & Juice \\
\hline Anisomeles indica & Jongli horinchi & Child fever & Leaves & Juice \\
\hline Artocarpus heterophyllus & Kathal & Diarrhea & Leaves & Decoction \\
\hline Averrhoa carambola & Kamranga & Jaundice & Fruit & Whole fruit \\
\hline Azadirachta indica & Neem & Allergy & Leaves & Paste and juice \\
\hline Basella alba & Pui Shaak & Anemia & Whole plant & Processed plant \\
\hline Brassica nigra & Sorisha & Arthritis & Leaves & Extract \\
\hline Bridelia retusa & Shukujjaa & Eczema & Leaf & Paste \\
\hline Canna indica & Kolaboti & Intestinal worms & Rhizome & Juice \\
\hline Carica papaya & Pepe & Diarrhea, jaundice & Fruit & Processed plant \\
\hline Cassia alata & Dilong & Eczema & Leaves & Paste \\
\hline Catharanthus roseus & Badam boot & Hypertension & Leaf & Juice \\
\hline Centella asiatica & Thankuni & Abdominal pain & Whole plant & Juice \\
\hline Cocos nucifera & Narikel & Jaundice & Fruit & Juice \\
\hline Commelina paludosa & Baat boitta shaak & Dysentery/diarrhea & Whole plant & Processed plant \\
\hline Costus speciosus & Ketoki & Bleeding from wounds, constipation & Root & Extract \\
\hline Curcuma longa & Holud & Eczema & Root & Paste \\
\hline Cymbopogon citratus & Dhan-shabarang & Common cold & Leaves & Extract \\
\hline Cymbopogon citratus & Leangra Gach & Snake bite & Root & Paste \\
\hline Cynodon dactylon & Durbaghash & Bleeding from wounds & Whole plant & Paste \\
\hline Dryopteris filix-mas & Dheki Shak & Common cold & Whole plant & Processed plant \\
\hline Eichhornia crassipes & Kochuripana & Asthma, allergy & Leaves & Juice \\
\hline Glinus oppositifolius & Gima shak & Allergy & Whole plant & Processed plant \\
\hline Gmelina arborea & Gamari & Abdominal pain & Root & Decoction \\
\hline Heptapleurum hypoleucum & Jharobbo hogeya & Diarrhea & Stem \& Root & Decoction \\
\hline Hibiscus sabdariffa & Amilla & Jaundice & Leaves & Decoction \\
\hline Holarrhena antidysenterica & Kurchi & Asthma & Root & Extract \\
\hline Hordeum vulgare & Barley & Diarrhea & Whole plant & Powder \\
\hline Jatropha gossypifolia & Titto long & Dengue fever & Seed & Powder \\
\hline Justicia adhatoda & Bashok & Common cold & Leaves & Juice \\
\hline Laurus nobilis & Tej pata & Eczema & Leaves & Infusion \\
\hline Leea macrophylla & Ash & Throat pain & Leaves & Juice \\
\hline Litsea monopetala & Shurjo Pata & Diarrhea & Leaves & Decoction \\
\hline Mikania micrantha & Ashamlata & Bleeding from wounds & Leaves & Paste \\
\hline Momordica charantia & Korolla & Measles & Fruit & Processed plant \\
\hline Musa paradisiaca & Kacha-kola & Blood dysentery & Fruit & Processed plant \\
\hline
\end{tabular}


Table 2 Ethnomedicinal plants used by the tribal people of Rangamati for treating different diseases (source: Medicinal Plants Database of Bangladesh [24-26]). A total of 62 medicinal plant species were found out of which 26 plants treat gastrointestinal ailments (GIA), 12 plants treat respiratory system disorders (RSD). Poisonous bites (PB) and skeleton muscular system disorders (SMSD) were treated by 2 plants. Endocrinal disorders (ED), throat pain, and hemorrhoids (HEM) were healed by 3 plants. Four plants were used to cure different types of fever (Fvr). For liver problems (LP), 5 plants were used. Dermatological infections/diseases (DID) were treated using 9 different plants. Three plants were used to treat hypertension (HTN) and 2 were used to treat anemia (Continued)

\begin{tabular}{|c|c|c|c|c|}
\hline Botanical/scientific name of the plant & Local name & Illness/disease treated & Part of the plant used & Mode of preparation \\
\hline Musa sapientum & Chompa-Kola & Blood dysentery & Fruit & Whole fruit \\
\hline Nelumbo nucifera & Roktopoddo & Piles & Root & Extract \\
\hline Ocimum tenuiflorum & Tulsi & Common cold & Leaves & Juice \\
\hline Pandanus odoratissimus & Keorakata & Abdominal pain & Root & Paste \\
\hline Phyllanthus emblica & Amloki & Common cold & Fruit & Fruit directly \\
\hline Piper betel & Paan pata & Gastric & Leaves & Whole leaf \\
\hline Plumbago indica & Agunitita & Blood dysentery & Leaf & Paste \\
\hline Psidium guajava & Peyara & Blood dysentery & Leaves & Paste \\
\hline Punica granatum & Bedana & Anemia & Fruit & Fruit directly \\
\hline Rourea minor & Kurochik-shak & Diarrhea & Leaf & Infusion \\
\hline Saccharum arundinaceum & Teng & Dysentery & Leaves & Decoction \\
\hline Saccharum officinarum & Aakh & Jaundice & Fruit & Juice \\
\hline Senna alata & Dao long & Ring worm & Leaves & Paste \\
\hline Stephania japonica & Thandamanik gach & Fever, headache, hypertension & Leaves & Juice \\
\hline Swertia chirayita & Chirota & Abdominal pain & Fruit & Processed plant \\
\hline Syzygium cumini & Kalojaam & Dysentery & Fruit & Whole fruit \\
\hline Tamarindus indica & Tetul & Hypertension & Fruit & Whole fruit \\
\hline Terminalia arjuna & Arjun & Allergy & Bark & Decoction \\
\hline Urena lobate & Barokra & Abdominal pain & Stem & Decoction \\
\hline Vitis sp. & Khoijong & Fever, common cold & Root & Juice \\
\hline Wedelia trilobata & Khetranga & Dysentery & Rhizome & Extract \\
\hline Zingiber officinale & Aada & Abdominal pain, common cold & Rhizome & Juice \\
\hline
\end{tabular}

\section{Ethnomedicinal plants used by the tribal people of Rangamati}

A total of 62 medicinal plants were found to treat several diseases (Table 2). Out of the 26 plants treating gastrointestinal ailments (GIA), some plants are $A z a$ dirachta indica, Canna indica, and Heptapleurum hypoleucum. Similarly, 12 plants including Allium sativum were found to treat respiratory system disorders (RSD). Poisonous bites (PB) and skeleton muscular system disorders (SMSD) were treated by 2 plants, including Alocasia cucullate and Brassica nigra respectively. Endocrinal disorders (ED), throat pain, and hemorrhoids (HEM) were healed by Andrographis paniculate, Leea macrophylla, and Nelumbo nucifera respectively. Four plants, together with Stephania japonica, were used as a remedy for different types of fever (Fvr). To treat liver problems (LP), five plants were used, including Carica papaya and Hibiscus sabdariffa. Dermatological infections/diseases (DID) were treated using nine different plants, like, Bridelia retusa, Cassia alata, and Curcuma longa. Three plants were used to treat hypertension (HTN) and two were used to treat Anemia, along with Stephania japonica and Basella alba respectively (Table 2). Heptapleurum hypoleucum was the most frequently used plant for the treatment of diarrhea as reported by the participant of this study which motivated us to choose this plant to further investigate its antimicrobial potentials against diarrhea-causing pathogens.

\section{Antibacterial assay}

The antibiotic disks used were ampicillin and gentamicin (for S. typhii and S. aureus), gentamycin (for E. coli), chloramphenicol (for $S$. pneumonae), and cefoxitin (for S. flexneri) (Fig. 4). The tests were repeated thrice to ensure the accuracy of the results. Among the three different types of extracts, the distilled water extract showed hardly any positive result. However, ethanolic and 

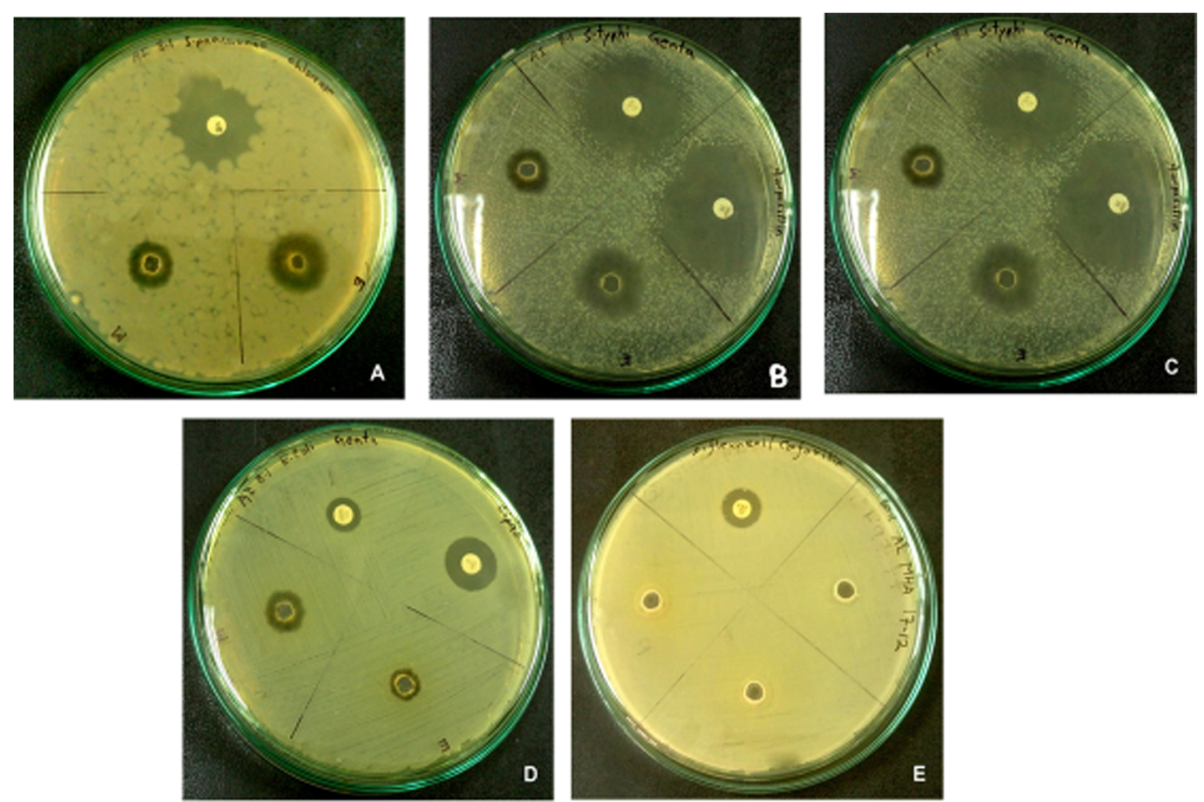

Fig. 4 Antibacterial effects of ethanolic and methanolic extracts of Heptapleurum hypoleucum against. a S. pneumonae. b S. aureus. c S. typhii. d E. coli. e Shigella flexneri. Ethanolic extract showed the highest zone of inhibition against Staphylococcus aureus (21 mm). Each of the plates is also showing the zone (white) produced by the commercial antibiotics against respective bacteria (as mentioned in Table 3)

methanolic extracts were able to show some positive results, but not against all the organisms (Fig. 5). Ethanolic extract showed the highest zone of inhibition against Staphylococcus aureus, which was $21 \mathrm{~mm}$ (Table 3). The average result of the three trials are given below (Fig. 5).

The activity index of $E$. coli was the highest in the ethanolic extract (value 0.81) as well as in the methanolic extract (value 1.18), while the lowest was seen for Shigella flexneri (value 0 for all solvents) (Fig. 6). The activity index for aqueous extract was 0 for $E$. coli, Salmonella typhi, and Shigella flexneri but had a value of
0.28 for Staphylococcus aureus and a value of 0.25 for Streptococcus pneumoniae. Here, the activity index of ethanolic extract for Streptococcus pneumoniae (0.73) is seen to be lower than for Staphylococcus aureus (0.78) and higher than Salmonella typhi (0.63) (Fig. 6).

\section{Summary of the phytochemical screening}

We have performed 6 tests for screening the phytochemical compounds in our extract. The tests are for alkaloids, phenolic compounds, flavonoids, saponins, steroids, and tannins. We got positive results for

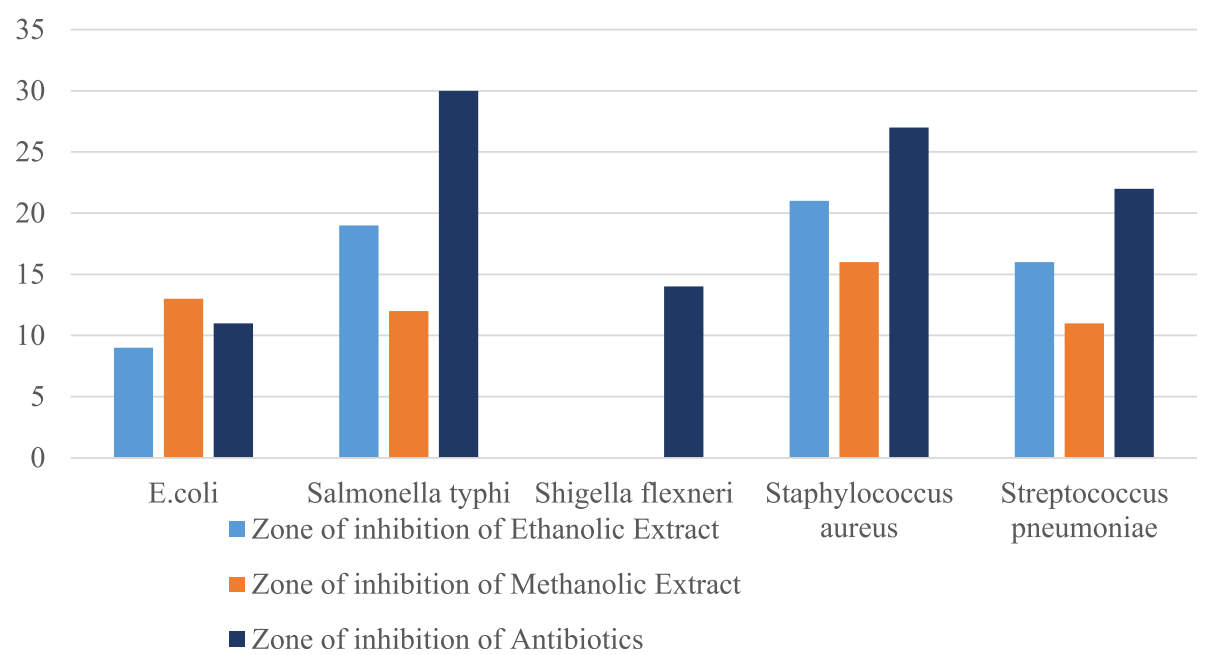

Fig. 5 Graphical representation zone of inhibition $(\mathrm{mm})$ of different extracts of Heptapleurum hypoleucum in comparison with antibiotic disks against some disease-causing microorganisms. Ethanolic extract showed the highest zone of inhibition against Staphylococcus aureus (21 mm) 
Table 3 Antibacterial test results of the ethanolic, methanolic, and aqueous extracts of Heptapleurum hypoleucum. Ethanolic extract showed the highest zone of inhibition against Staphylococcus aureus (21 mm)

\begin{tabular}{|c|c|c|c|c|c|}
\hline \multirow{2}{*}{$\begin{array}{l}\text { Extract } \\
\text { (quadrant) }\end{array}$} & Escherichia coli & Salmonella typhi & Shigella flexneri & Staphylococcus aureus & Streptococcus pneumoniae \\
\hline & $\begin{array}{l}\text { Antibiotic used- } \\
\text { Gentamicin }\end{array}$ & $\begin{array}{l}\text { Antibiotic used- } \\
\text { Gentamicin }\end{array}$ & $\begin{array}{l}\text { Antibiotic used- } \\
\text { Cefoxitin }\end{array}$ & $\begin{array}{l}\text { Antibiotic used- } \\
\text { Gentamicin }\end{array}$ & $\begin{array}{l}\text { Antibiotic used- } \\
\text { Chloramphenicol }\end{array}$ \\
\hline \multicolumn{6}{|c|}{ The average diameter of zone of inhibition $(\mathrm{mm})$ of antibiotics and different extracts/quadrant } \\
\hline Antibiotic & 11 & 30 & 14 & 27 & 22 \\
\hline Ethanol & 9 & 19 & 0 & 21 & 16 \\
\hline Methanol & 13 & 12 & 0 & 16 & 11 \\
\hline Distilled water & 0 & 0 & 0 & 11 & 6 \\
\hline \multicolumn{6}{|c|}{ Activity index/quadrant } \\
\hline Ethanol & 0.81 & 0.63 & 0 & 0.78 & 0.73 \\
\hline Methanol & 1.18 & 0.4 & 0 & 0.59 & 0.5 \\
\hline
\end{tabular}

alkaloids, phenolics, flavonoids, and steroids. However, negative results were observed for saponins and tannins (Fig. 7). The result of the phytochemical screening has been summarized in Table 4.

\section{Discussion}

Tribal people have been using plants to treat different kinds of diseases for a long time. Years of experience has made them a "knowledge house" on herbal remedies. An ethnobotanical survey of medicinal plants in the Chittagong Hill Tracts has revealed that 56 plant species were used by the tribal people only to treat dermatological disorders [27]. In another ethnobotanical study, conducted among Pangkhua community in Bilaichari, Bangladesh, revealed the traditional use of 117 plant species to treat 11 categories of ailments, recorded from 218 traditional healers and elderly men and women [28]. Our study also found that 62 plant species were used by the tribal people of Rangamati to treat almost 20 different diseases, namely abdominal pain, common cold and sneezing, injury, diarrhea, and dysentery. In this study, about $77 \%$ of the participants reported that they had recovered from the above-mentioned diseases within 1 to 10 days using only the medicinal plants as a remedy. In contrast, only $2-3 \%$ of the participants took additional medications (besides the medicinal plants) which might contribute to their quick recovery. Our study also found that age has significant influence when choosing medicinal plants over traditional medications. Older people naturally ought to have a better understanding and greater knowledge about the traditional use of medicinal plants as pharmaceuticals or modern medicines were unavailable in their era. The fact of having

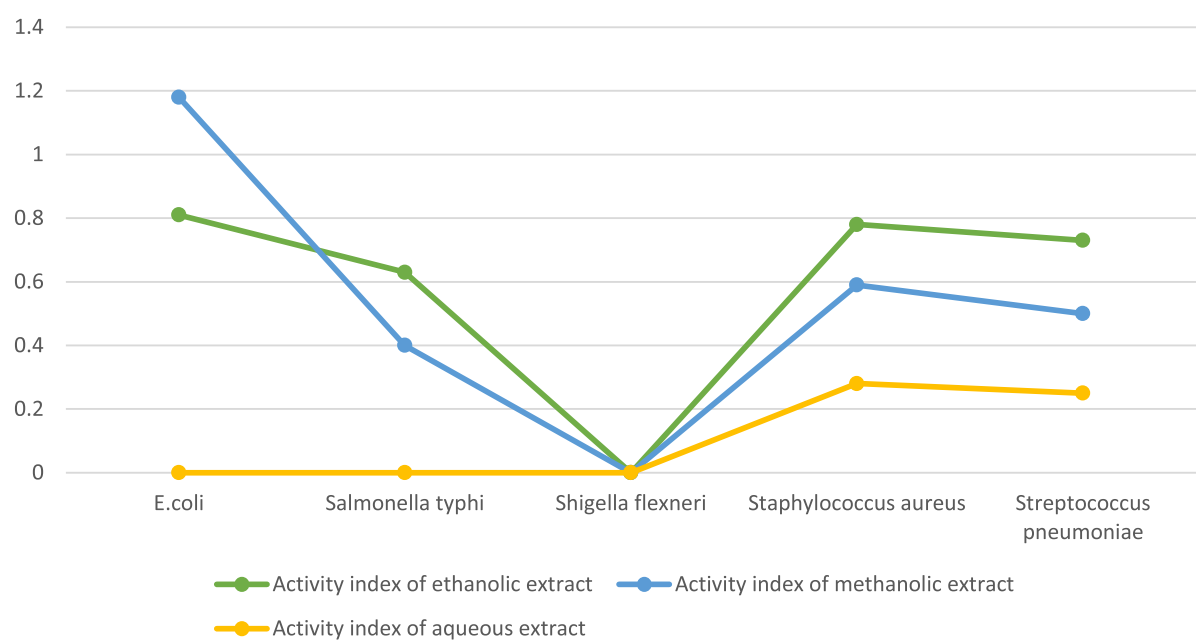

Fig. 6 Activity index of ethanolic, methanolic, and aqueous extracts against different microorganism. E. coli had the highest activity index in the ethanolic extract (value 0.81) as well as in the methanolic extract (value 1.18), while the lowest was seen for Shigella flexneri (value 0 in all solvents) 


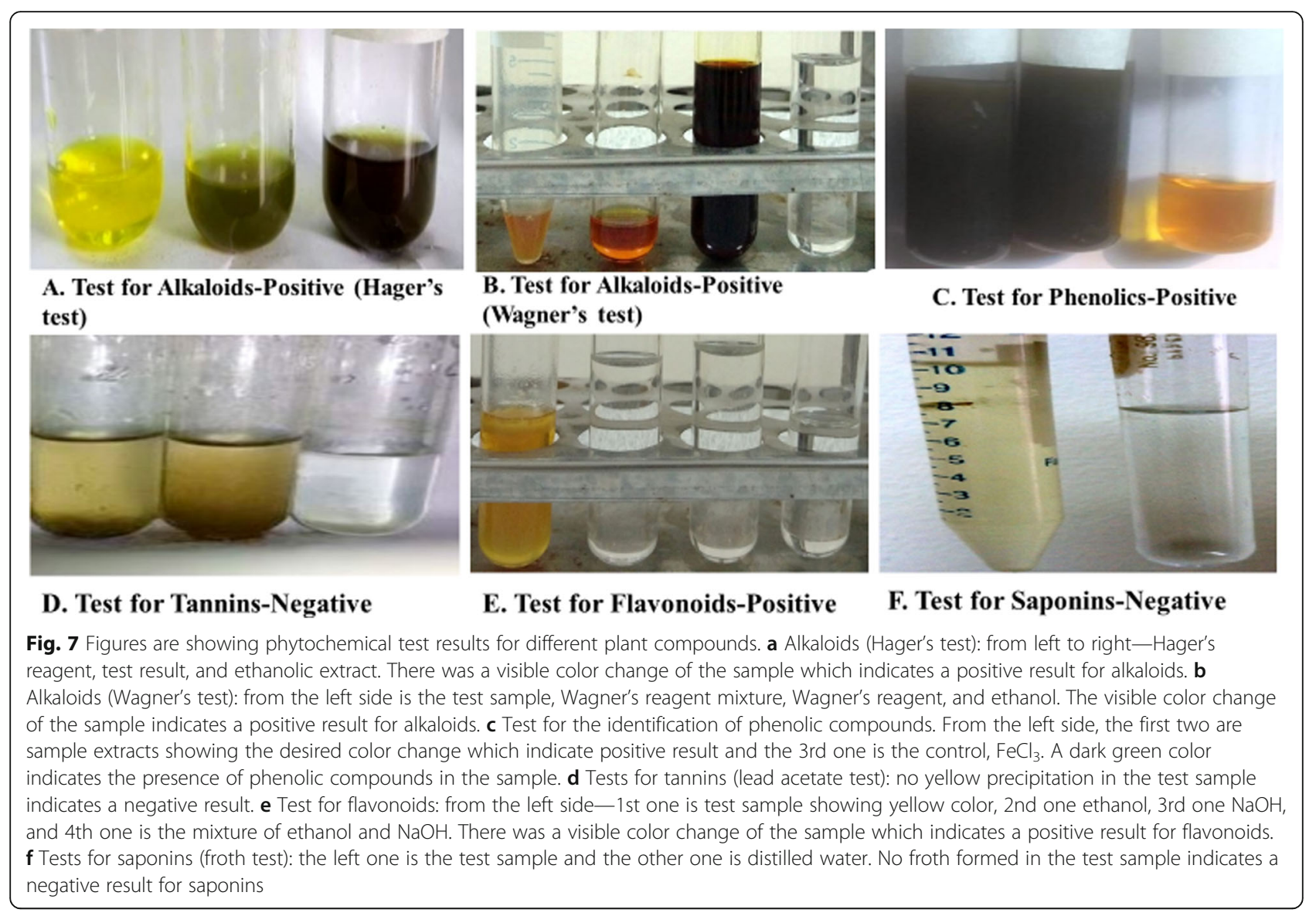

superior knowledge about the use of medicinal plants is reflected to some extent in this survey as about $34 \%$ of the total people questioned aged above 50 years old. While using plants as remedies against diseases, leaves $(42.68 \%)$ were found to be the most used part as medicine as they are most easily accessible can also be used in different ways very easily. Different plants and their parts may have a distinct mode of preparations and are preferred over one another according to the user's flexibility and satisfaction. The simplest and most common modes of preparation are

Table 4 Phytochemical analysis showing positive results for alkaloids, flavonoids, and steroids. In contrast, our study also indicates the absence of saponins and tannins in the sample

\begin{tabular}{ll}
\hline Name of the phytochemical & Result \\
\hline Alkaloids & Positive \\
Phenolics & Positive \\
Flavonoids & Positive \\
Saponins & Negative \\
Steroids & Positive \\
Tannins & Negative \\
\hline
\end{tabular}

extraction, juice, paste, and decoction. In this study, most people used paste (33\%).

Knowledge regarding medicinal plants is obtained from different sources such as family, the local Kaviraaj, and the local people. Consequently, the information gained is discrete, given that, it was found that several plants or plant parts were used for treating the same disease. For instance, for treating the common cold, "Tulsi" (Ocimum tenuiflorum), "Bashok" (Justicia adhatoda), "Dhan-shabarang" (Cymbopogan citratus) etc. were used. Supporting this fact, a study conducted in the Lushai community of Bandarban district of Bangladesh, pointed out that 37 different plant species were used to treat diarrhea and 40 plant species were used to treat dysentery [16]. On the other hand, one particular plant was used to treat many different diseases. The plant "Thankuni" (Centella asiatica) was used to treat both diarrhea and gastric. Similarly, "Ghritkumari" (aloe vera) is used as a remedy for both constipation, due to its laxative property which relieves constipation by promoting intestinal motility, as well as diabetes, as aloe vera is believed to improve insulin secretion and enhance pancreatic $\beta$ cell function $[29,30]$. 
The plant Heptapleurum hypoleucum was selected for further study as this has been used most commonly to treat diarrhea in the tribal areas. The stem part of the plant was collected and processed into powder and examined to assay its antibacterial activity against several diarrhea-causing bacteria. From the trials, the highest inhibition zone was seen by ethanolic extract against Staphylococcus aureus, which was $21 \mathrm{~mm}$. In contrast, another research work with medicinal plants showed that the chloroform extract of $P$. sagitatta plant showed an inhibition zone of $16 \mathrm{~mm}$ against Staphylococcus aureus [31]. Comparing the two, the $21 \mathrm{~mm}$ inhibition zone from the ethanolic extract seems very significant. However, no zone was observed against Shigella flexneri both in methanolic and ethanolic extract. Additionally, the aqueous extract showed results only against $S$. aureus and S. pneumoniae. Although the activity for commercial antibiotics is much higher than herbal plants, the use of medicinal plants should be encouraged as the overuse of antibiotics will eventually lead to the development of superbugs which will hinder proper treatment. As the extract of our medicinal plant was not purified and yet we found a comparable value $(21 \mathrm{~mm}$ in ethanolic extract and $27 \mathrm{~mm}$ in commercial antibiotic against Staphylococcus aureus), we believe purification of the plant extract will increase its activity significantly.

Medicinal plants certainly contain various types of minerals and both primary and secondary metabolites and for these, they confer antimicrobial effects [32-34]. In this study, phytochemical analysis of the plant extract showed both positive and negative results for several compounds. The plant extract has shown to contain alkaloids, phenolics, steroids, and flavonoids, whereas a negative result was observed for saponins and tannins, which indicates that Heptapleurum hypoleucum lack these two phytochemicals.

\section{Conclusion}

Ethnoscience and indigenous knowledge need to be consolidated with modern biotechnological techniques and approaches to achieve the desired end products with scientific validation and to make the most use of the vast amount of natural resources around us. This study suggests that various medicinal plants can serve as an alternative to the mainstream drugs to which bacteria are gradually becoming resistant. From the results, Heptapleurum hypoleucum has not only shown significant antibacterial effect against several diarrhea-causing pathogens, but we also found some medically important constituents after conducting the phytochemical tests; thus, further research is recommended to purify these phytochemicals to understand the full potentials of this medicinal plant.

\section{Abbreviations}

MHA: Mueller Hinton Agar; Al: Activity index; GIA: Gastrointestinal ailments; RSD: Respiratory system disorders; PB: Poisonous bites; SMSD: Skeleton muscular system disorders; ED: Endocrinal disorders; HEM: Hemorrhoids; LP: Liver problems; DID: Dermatological infections and diseases; HTN: Hypertension

\section{Acknowledgements \\ The authors are thankful to the BRAC University, Bangladesh, for the financial and infrastructural support provided for this study. The authors are cordially grateful to the tribal communities inhabiting in different localities of Rangamati district because of their kind support and cooperation during the field surveys. A lot of thanks to all the traditional health practitioners and people involved in the interviews for providing information about the medicinal applications of the plants.}

\section{Authors' contributions}

$\mathrm{Al}$ and RUZ were involved in conception and design of the experiments. Al conducted the survey. Al, RUZ, and KK contributed to perform the experiments. Al, MMAA, and GK analyzed the data and contributed to drafting the article. SAM helped preparing and revising the manuscript. RUZ made the final approval of the version to be published. All authors contributed to revising it critically for important intellectual content. All authors read and approved the final manuscript.

\section{Funding}

This research received no external funding.

\section{Availability of data and materials}

All data generated or analyzed during this study are included in this published article.

Ethics approval and consent to participate

Prior informed verbal consent was always obtained before interview and comply with local guidelines.

\section{Consent for publication}

Not applicable.

\section{Competing interests}

The authors declare that they have no competing interests.

\section{Author details}

${ }^{1}$ Biotechnology Program, Department of Mathematics and Natural Sciences, School of Sciences, BRAC University, Dhaka, Bangladesh. ${ }^{2}$ Department of Biotechnology and Genetic Engineering, Islamic University of Kushtia, Kushtia, Bangladesh.

Received: 24 February 2020 Accepted: 30 April 2020

Published online: 15 June 2020

References

1. Mulat M, Pandita A, Khan F (2019) Medicinal plant compounds for combating the multi-drug resistant pathogenic bacteria: a review. Current pharmaceutical biotechnology 20(3):183-196

2. Al-Asmari AK, Athar MT, Kadasah SG (2017) An updated phytopharmacological review on medicinal plant of Arab region: Apium graveolens linn. Pharmacognosy reviews 11(21):13

3. Subramani, R., Narayanasamy, M. \& Feussner, K. Plant-derived antimicrobials to fight against multi-drug-resistant human pathogens. 3 Biotech 7, 172 (2017). https://doi.org/10.1007/s13205-017-0848-9.

4. Jeelani SM, Rather GA, Sharma A, Lattoo SK (2018) In perspective: potential medicinal plant resources of Kashmir Himalayas, their domestication and cultivation for commercial exploitation. Journal of applied research on medicinal and aromatic plants 8:10-25

5. Barbieri R, Coppo E, Marchese A, Daglia M, Sobarzo-Sánchez E, Nabavi SF, Nabavi SM (2017) Phytochemicals for human disease: an update on plantderived compounds antibacterial activity. Microbiological research 196:44-68

6. Huyut, Z., Beydemir, Ş., \& Gülçin, İ. (2017). Antioxidant and antiradical properties of selected flavonoids and phenolic compounds. Biochemistry research international, 2017 
7. Sulaiman, I. S. C., Sukhi, S., \& Mohamad, A. (2018). Roles of phytochemicals in the prevention and treatment of various diseases. In Phytochemistry (pp. 147-164). Apple Academic Press

8. Khameneh B, Iranshahy M, Soheili V et al (2019) Review on plant antimicrobials: a mechanistic viewpoint. Antimicrob Resist Infect Control 8: 118. https://doi.org/10.1186/s13756-019-0559-6

9. Othman L, Sleiman A, Abdel-Massih RM (2019) Antimicrobial activity of polyphenols and alkaloids in Middle Eastern plants. Frontiers in microbiology 10:911. https://doi.org/10.3389/fmicb.2019.00911

10. Kiokias S, Proestos C, Oreopoulou V (2018) Effect of natural food antioxidants against LDL and DNA oxidative changes. Antioxidants 7(10):133

11. Santhosh Kumar, J. U., Krishna Chaitanya, M. J., Andrew, J., \& Semotiuk, Krishna, V. (2019). Indigenous knowledge on medicinal plants used by ethnic communities of South India. Ethnobotany Research and Applications, $18,1-112$.

12. Afrisham R, Aberomand M, Ghaffari MA, Siahpoosh A, Jamalan M (2015) Inhibitory effect of Heracleum persicum and Ziziphus jujuba on activity of alpha-amylase. Journal of Botany 2015. https://doi.org/10.1155/2015/824683

13. Kooti W, Farokhipour M, Asadzadeh Z, Ashtary-Larky D, Asadi-Samani M (2016) The role of medicinal plants in the treatment of diabetes: a systematic review. Electronic physician 8(1):1832-1842. https://doi.org/10. 19082/1832

14. Mahbubur Rahman AHM (2015) Ethnobotanical survey of antidiabetic medicinal plants used by Santal tribe of Joypurhat district. Bangladesh. International Journal of Research in Pharmacy and Biosciences. 2:19-26

15. Rahman A, Jamila M (2016) Ethnobotanical study of traditional medicinal plants used by the Santal tribal practitioners at the Village Jamtala of Chapai Nawabganj District, Bangladesh. Journal of Progressive Research in Biology 3(1):142-159

16. Uddin, M. S., Chowdhury, V., Uddin, S. B., Mazumder, A. A. M., \& Howlader, M. S. A. (2015). Ethnobotanical survey of medicinal plants used by the Lushai community in Bandarban District, Bangladesh. Journal of Advanced Botany and Zoology, 2(4). DOI: 10.15297/JABZ.V214.04.

17. Keya MA, Rahman AHMM (2017) Angiosperm diversity at the Village Sabgram of Bogra, Bangladesh with emphasis on medicinal plants. American Journal of Plant Biology 2(1):25-34

18. Tripathi J, Singh R, Ahirwar RP (2017) Ethnomedicinal study of plants used by tribal person for diarrhoea diseases in Tikamgarh District MP. Journal of Medicinal Plants 5(1):248-253

19. CLSI, Performance standards for antimicrobial disk susceptibility tests, approved standard, 7th ed., CLSI document M02-A11. Clinical and Laboratory Standards Institute, 950 West Valley Road, Suite 2500, Wayne, Pennsylvania 19087, USA, 2012.

20. Puri S, Kumar V (2019) Phytochemical screening of medicinal plants used by tribal migratory shepherds in Western Himalaya. Annals of Biology 35(1):11-14

21. Solanki SL, Modi CM, Patel HB, Patel UD, Bhadarka DH (2019) Phytochemical screening and thin-layer chromatography of six medicinal plants from the surroundings of Junagadh, Gujarat, India. Journal of Pharmacognosy and Phytochemistry 8(4):3122-3126

22. Yadav R, Khare RK, Singhal A (2017) Qualitative phytochemical screening of some selected medicinal plants of shivpuri district (mp). Int. J. Life. Sci. Scienti. Res 3(1):844-847

23. Khan WM, Shah SZ, Khan MS, Akhtar N, Khan H (2016) A preliminary phytochemical screening of medicinal plants: a case study of selected plant species at three phenological stages. Pakistan Journal of Weed Science Research 22(2)

24. Medicinal Plants Database of Bangladesh (https://www.mpbd.info/index.php)

25. Hasan, M., Arabia, S., Hossain, S.A., \& Ali, A. (2014). MeMedicinal Plants Database of Bangladeshdicinal plant diversity in Chittagong, Bangladesh: a database of 100 medicinal plants.

26. Mumtaz A, Ashfaq UA, ul Qamar MT, Anwar F, Gulzar F Ali MA, Pervez MT (2017) MPD3: a useful medicinal plants database for drug designing. Natural product research, 31(11):1228-1236

27. Islam Setu N, Brishty SR, Anwar M, Jahan R, Mia MMK, Islam M, Fahim Kadir M (2020) Ethnobotanical study on medicinal plants for dermatological disorders at Chittagong Hill Tracts, Bangladesh. Pharmaceutical and Biomedical Research 6(2):1-12

28. Faruque MO, Feng G, Khan MNA et al (2019) Qualitative and quantitative ethnobotanical study of the Pangkhua community in Bilaichari Upazilla, Rangamati District, Bangladesh. J Ethnobiology Ethnomedicine 15:8. https://doi.org/10.1186/s13002-019-0287-2
29. Noor A, Gunasekaran S, Vijayalakshmi MA (2017) Improvement of insulin secretion and pancreatic $\beta$-cell function in streptozotocin-induced diabetic rats treated with Aloe vera extract. Pharmacognosy research 9(Suppl 1):S99

30. Vakili M, Ahmadipour S, Rahmani P (2018) Remedies and herbal plants for constipation in children

31. Chowdhury SR, Akter S, Sharmin T, Islam F, Quadery TM (2013) Antimicrobial activity of five medicinal plants of Bangladesh. Journal of Pharmacognosy and Phytochemistry 2(1):164

32. Ghuman S, Ncube B, Finnie JF, McGaw LJ, Coopoosamy RM, Van Staden J (2016) Antimicrobial activity, phenolic content, and cytotoxicity of medicinal plant extracts used for treating dermatological diseases and wound healing in KwaZulu-Natal, South Africa. Frontiers in pharmacology 7:320

33. Mohamad OA, Li L, Ma JB, Hatab S, Xu L, Guo JW et al (2018) Evaluation of the antimicrobial activity of endophytic bacterial populations from Chinese traditional medicinal plant licorice and characterization of the bioactive secondary metabolites produced by Bacillus atrophaeus against Verticillium dahliae. Frontiers in microbiology 9:924

34. Wang L, Chen X, Wu A (2016) Mini review on antimicrobial activity and bioactive compounds of Moringa oleifera. Med. Chem 6:578-582

\section{Publisher's Note}

Springer Nature remains neutral with regard to jurisdictional claims in published maps and institutional affiliations.

\section{Submit your manuscript to a SpringerOpen ${ }^{\circ}$ journal and benefit from:}

- Convenient online submission

- Rigorous peer review

- Open access: articles freely available online

High visibility within the field

- Retaining the copyright to your article

Submit your next manuscript at $\boldsymbol{\nabla}$ springeropen.com 